\title{
The Analysis of the Factors Related to the Quality of Work-Life of the Workers at PT Semen Indonesia Tuban Factory
}

\author{
Analisis Faktor yang Berhubungan dengan Kualitas Kehidupan Kerja pada \\ Tenaga Kerja PT Semen Indonesia Pabrik Tuban
}

\author{
Rachmawati Maulidhina \\ PT Hikari Teknologi Indonesia \\ Jalan Raya Sukomulyo KM 23, Romokalisari, Manyar, Gresik, East Java 61151, Indonesia
}

\begin{abstract}
Introduction: Quality of work-life (QWL) is an essential concept related to the life of a worker. QWL is made to realize the balance between the workers' needs and interests, as well as the workload to ensure work satisfaction and the organization's productivity. PT Semen Indonesia is the biggest cement producing company in Java Island. The company manages the human resources to achieve job satisfaction by carrying out the QWL program. This research aims to analyze the factors related to the QWL that can lead to the workers' QWL, especially to the packers and loader workers at PT Semen Indonesia, Tuban Factory. Methods: This research is completed by implementing the cross-sectional design with a qualitative approach. The population of this research is all workers in the packer and loader department Tuban IVth plant, as many as 80 people, while the sample consists of 45 workers chosen by the simple random sampling method. Seven identified factors from the literature review are the workers' involvement, balanced compensations, a sense of security towards the work, occupational safety and health, career development, working relationships, and pride in the company. Results: indicate that there is a significant and positive correlation between all seven factors and the QWL. Conclusioan: That developing a non-financial compensation, socializing career development programs, and job guarantee will lead to job satisfaction as well as to ensure the organization's productivity.
\end{abstract}

Keywords: job satisfaction, packers and loaders, productivity, quality of work-life

\section{ABSTRAK}

Pendahuluan: Kualitas kehidupan kerja merupakan konsep penting yang memiliki pengaruh pada kehidupan pekerja. Kualitas kehidupan kerja ditujukan untuk mewujudkan keseimbangan baik antara kebutuhan dan minat tenaga kerja dengan beban kerja yang dihadapinya untuk memastikan kepuasan tenaga kerja dan produktivitas organisasi. PT. Semen Indonesia merupakan perusahaan penghasil semen terbesar di Pulau Jawa. Perusahaan melaksanakan pengelolaan sumber daya manusia untuk mewujudkan kepuasan kerja, salah satunya adalah dengan melaksanakan program-program kualitas kehidupan kerja. Tujuan penelitian ini adalah menganalisa faktor yang berhubungan dan dapat mewujudkan kualitas kehidupan kerja pada packersdan porters PT. Semen Indonesia Pabrik Tuban. Metode: Penelitian ini dilakukan dengan rancangan cross-sectional dengan pendekatan kualitatif. Populasi penelitian adalah seluruh tenaga kerja bagian operasi packer dan loader plant Tuban IV sejumlah 80 orang dan sampel penelitian terdiri dari 45 tenaga kerja yang dipilih secara simple random sampling. Tujuh faktor yang diidentifikasi melalui studi literatur adalah keterlibatan tenaga kerja, kompensasi yang seimbang, rasa aman terhadap pekerjaan, keselamatan dan kesehatan kerja, pengembangan karier, hubungan kerja dan rasa bangga terhadap perusahaan. Hasil: Penelitian menunjukkan bahwa terdapat hubungan yang signifikan dan positif antara ketujuh faktor dengan kualitas kehidupan kerja. Simpulan: Mengembangkan kompensasi non finansial, mensosialisasikan program pengembangan karier dan jaminan ketenagakerjaan akan mewujudkan kepuasan kerja dan memastikan produktivitas organisasi.

Kata kunci: kualitas kehidupan kerja, kepuasan kerja, produktivitas, packers and porters

Author for Correspondence:

Rachmawati Maulidhina

Email: rmaulidhina@gmail.com

Telephone: +6281554821333

(C2019 IJOSH. Open access under CC BY NC-SA license doi: 10.20473/ijosh.v8i3.2019.310-320. Received June 05, 2018, received in revised form February 07, 2019, Accepted November 04, 2019, Published: December 2019 


\section{INTRODUCTION}

The worker is the main asset of a company as well as one of the living resources that can be developed. Workers also role as thinkers, planners, and activity controllers. Thus, in order to have qualified human resources in an organization, good management of human resources is indispensable (Hasibuan, 2005). Qualified human resources can be defined as a resource that can contribute to the company in the form of maximum achievements, which in order to realize those achievements, the fulfillment of the workers' needs Recently, workers tend to regard their quality of life when fulfilling their needs. Hence, the issues on quality of work-life (QWL) are to be studied by the company as one of the endeavors to develop the human resources (Lian, Lin and $\mathrm{Wu}, 2007)$.

Wijono in his book on industrial psychology, affirmed that QWL is a special factor that can realize job satisfaction (Wijono, 2010). A company with a high-performance demand must have a high level of job satisfaction as one of the attempts to increase the workers' productivity. According to the research titled "The Influence of Quality of Work-Life to the Work Satisfaction, Organizational Commitment, Turnover Intention, and Work Stress: A Study on a BMT in Kudus", there is a significant and positive influence between the QWL and the job satisfaction as well as the organizational commitment. In other words, it can be implied that the better the QWL of a worker, the higher the job satisfaction level. Similar research was also carried out by Dhamayanti (2017) at PT Inti Abadi Kemasindo, a subsidiary of PT Indofood Sukses Makmur which is engaged in the packaging industry. After completing the research on 100 respondents, Dhamayanti (2017) concluded that there is a significant correlation between the dependent variable, which is job satisfaction, and the QWL as the independent variable.

On the contrary, job dissatisfaction may result in several issues on both the workers themselves and the company. The issues on the workers caused by job dissatisfaction can be in the form of diseases, such as migraine and fatigue (Wijono, 2010). Additionally, it has been noticed that job dissatisfaction is closely related to the health of the workers. Some studies have concluded that workers with job dissatisfaction tend to undergo a wide range of health issues, for instance, headache and heartache (Robbins, 2001).

Job satisfaction is often assumed as one of the psychological factors that had the workers undergone work stress. Wijono (2010) proposed that there is a correlation between job satisfaction and work stress suffered by workers. The correlation is identified as a reflective correlation (reflective effect) between the individual experience and her/his perception towards the workplace. In other words, it can be presumed that the more the work stress, the less the job satisfaction.

QWL, according to Cascio (1998), consists of the factors that as a whole can realize the needs of the workers. Those factors comprise the workers' involvement, balanced compensations, a sense of security towards the work, occupational safety and health, career development, working relationship, and pride in the company. The development of QWL aims to balance the work with the needs, interests, and pressure encountered by the workers to increase the company's productivity as well as to decrease the turnover level of the workers.

PT Semen Indonesia is the largest cement industry in Java Island with an initial production capacity of 25,000 tons of cement per year. Furthermore, PT Semen Indonesia is listed as the first Multinational State-owned Enterprise (SOE) in Indonesia. The great responsibility to meet the demand of the consumers from Indonesia and abroad makes the workers become eminent resources to the success of the company.

Suci (2017) in her research found that most of the packer and loader workers at PT Semen Indonesia (70\%) have a moderate stress level, while the rest have a high-stress level. This fact alone should have been a wake-up call for the company to pay serious attention and to manage the human resources in the best way, which includes the fulfillment of the QWL.

Therefore, based on the background that has been elucidated, this research aims to analyze the factors related to the QWL of the workers in the production department at PT Semen Indonesia (Persero) Tbk, Tuban Factory.

\section{METHODS}

This research is observational research in which the authors observe and record every detail related to the variables of the research. Moreover, this research applies a cross-sectional approach. The method implemented is analytical research, providing the aim of this research is to identify the correlation between two variables, i.e., the dependent and independent variables. 
This research was carried out in the packer and loader operation departments at PT Semen Indonesia, Tuban Factory, Tuban IVth Plant. The population of this research was 80 workers in the packer and loader operation departments that were selected by using the simple random sampling technique. ), the ideal number of samples of research ranges from 30 to 500 respondents. Thus, by implementing the Lemshow's formula, there were 45 people selected as the sample of this research to collect accurate and comprehensive information regarding the works. Besides, the respondents must have had been working for more than a year in the company when this research was carried out, with the assumption that they have been fully understood the works and the organization conditions. The data collection was completed during the first two weeks of March 2018.

There were two variables being scrutinized in this research, namely dependent and independent variables. The dependent variables were the factors of QWL, while the independent variable was the QWL itself. The factors of QWL used in this research comprised the workers' involvement, balanced compensations, a sense of security towards the work, occupational safety and health, career development, working relationship, and pride in the company (Cascio, 1998).

The data used in this research were in the form of primary and secondary data. The primary data was obtained through the questionnaire fulfillment as the research instrument, which was adapted from the questionnaire made by the National Institute of Occupational Safety and Health titled Quality of Worklife (National Institute of Occupational Safety and Health, 2013). On the other hand, the secondary data was obtained from the company profile and literature studies. After that, all the collected data were scrutinized through several steps, namely editing, coding, entry, sorting, and data tabulating. Tables, frequency, narration, and cross-tabulation were used to describe the results of the research. Moreover, the Spearman's correlation test as the statistical analysis was used to identify the correlation between variables, with significance value $(\alpha)$ of 0.05 .

\section{RESULTS}

\section{The Respondents' Characteristics}

By referring to the respondents' characteristics, namely the age, education background, marital status, and years of service, the frequency distribution of the packer and loader workers were displayed in Table 1. Based on Table 1, it can be noticed that the majority of the respondents categorized in the age group of 21-30 years old, which were 35 people $(77.8 \%)$, high school graduates group (42 people or $93.3 \%$ ), married group (26 people or $57.8 \%$ ), and the group of those who had been serving the company for about 6-10 years (48.9\%).

\section{The Factors of Quality of Work-Life}

The workers' involvement can be described as the workers' perception of every opportunity to actively participate in decision-making activities or acceptance of ideas that are related to the leader. Table 2 below shows that more than half of the respondents $(68.9 \%)$ were discovered attaining a moderate-score of involvement. Meanwhile, a highscore and a low-score of involvements were attained by 8 and 6 workers, respectively.

The balanced compensations in this research are outlined as the workers' perception of the incentives received. Table 2 indicates that $57.8 \%$

Table 1.The Frequency Distribution of the Characteristics of the Packer and Loader Workers at PT Semen Indonesia Tuban Factory in 2018

\begin{tabular}{ccc}
\hline $\begin{array}{c}\text { Characteristics } \\
\text { of the } \\
\text { Respondents }\end{array}$ & $\begin{array}{c}\text { Frequency } \\
\text { (n) }\end{array}$ & $\begin{array}{c}\text { Percentage } \\
(\%)\end{array}$ \\
\hline Age Group & & 77.8 \\
21-30 years old & 35 & 22.2 \\
31-40 years old & 10 & 100 \\
\hline Total & 45 & \\
\hline Educational & & 6.7 \\
Attainment & 3 & 93.3 \\
Middle School & 42 & 100 \\
High School & 45 & \\
\hline Total & & 42.2 \\
\hline Marital Status & 19 & 57.8 \\
Single & 26 & 100 \\
Married & 45 & \\
\hline Total & & 40.0 \\
\hline Years of Service & 18 & 48.9 \\
$\leq 5$ years & 22 & 11.1 \\
\hline 6-10 years & 5 & 100 \\
$>10$ years & 45 & \\
\hline Total & & \\
\hline & & \\
\hline
\end{tabular}


of the respondents obtained a moderate-score of balanced compensation.

A sense of security towards the work is believed as the workers' perception of the company stability, waging system, and employment contract. Based on the results of the research presented in Table 2, it can be noticed that 24 out of 45 workers (53.3\%)

Table 2. The Frequency Distribution of the Packer and Loader Workers based on the Factors of Quality of Work-Life in 2018

\begin{tabular}{|c|c|c|}
\hline Factors of QWL & $\begin{array}{l}\text { Frequency } \\
\text { (n) }\end{array}$ & $\begin{array}{c}\text { Percentage } \\
(\%)\end{array}$ \\
\hline \multicolumn{3}{|l|}{ Workers' Involvement } \\
\hline Low & 6 & 13.3 \\
\hline Moderate & 31 & 68.9 \\
\hline High & 8 & 17.8 \\
\hline Total & 45 & 100 \\
\hline \multicolumn{3}{|c|}{ Balanced Compensations } \\
\hline Low & 16 & 35.5 \\
\hline Moderate & 26 & 57.8 \\
\hline High & 3 & 6.7 \\
\hline Total & 45 & 100 \\
\hline \multicolumn{3}{|c|}{ A Sense of Security towards the Work } \\
\hline Low & 9 & 20.0 \\
\hline Moderate & 12 & 26.7 \\
\hline High & 24 & 53.3 \\
\hline Total & 45 & 100 \\
\hline \multicolumn{3}{|c|}{ Occupational Safety and Health } \\
\hline Low & 7 & 15.6 \\
\hline Moderate & 27 & 60.0 \\
\hline High & 11 & 24.4 \\
\hline Total & 45 & 100 \\
\hline \multicolumn{3}{|l|}{ Career Development } \\
\hline Low & 4 & 8.9 \\
\hline Moderate & 26 & 57.8 \\
\hline High & 15 & 33.3 \\
\hline Total & 45 & 100 \\
\hline \multicolumn{3}{|l|}{ Work Relationship } \\
\hline Low & 5 & 11.1 \\
\hline Moderate & 28 & 62.2 \\
\hline High & 12 & 26.7 \\
\hline Total & 45 & 100 \\
\hline \multicolumn{3}{|c|}{ Sense of Pride to the Company } \\
\hline Low & 4 & 8.9 \\
\hline Moderate & 32 & 71.1 \\
\hline High & 9 & 20.0 \\
\hline Total & 45 & 100 \\
\hline
\end{tabular}

obtained a high-score of a sense of security towards the work.

Occupational safety and health are defined as the workers' perception of the safe and conducive working environment and the work. By referring to Table 2, it can be seen that $60 \%$ of the respondents attained a moderate-score of occupational safety and health in the company.

Career development referred to in this research is the workers' perception of the opportunity to knowledge acquirement, skill development, and job promotion. According to Table 2 above, it can be seen that $57.8 \%$ of the respondents attained a moderate-score on the career development category.

A working relationship is described as the workers' perception of the relationships with coworkers and supervisors, communication, and the company's efforts to solve every problem as one of the indicators of QWL. Table 2 displayed that regarding this factor, $62.2 \%$ of the respondents obtained a moderate-score of a working relationship.

Pride in the company can also be stated as the workers' perception of the sense of belonging and a sense of loyalty to the company. Table 2 above indicated that the bigger part of the workers, as much as $71.1 \%$, attained a moderate-score on the sense of pride in the company.

\section{Levels of Quality of Work-Life}

The results of the data analysis on the QWL of the workers in the packer and loader departments Tuban IVth plant are presented in Table 3 below. Furthermore, it can be remarked that the implementation of the programs regarding the QWL provides positive impacts on the workers since there are more than half of the respondents (66.7\%) stated that they have a moderate-level of QWL.

\section{The Correlation between the Workers' Involvement and Quality of Work Life}

The correlation between the workers' involvement and QWL is assessed by implementing the Spearman's correlation test. Referring to the results of the test displayed in Table 4 below, it can be perceived that there were two respondents $(40 \%)$ with a low-score of involvement and a low-level of QWL. On the other hand, it was found that there were four respondents $(21.1 \%)$ with a high-score of involvement and a high-score of QWL. 
Spearman's rho correlation test showed a significant value of 0.012 , which meant that there is a significant and positive correlation between the two variables with the correlation coefficient value of 0.372 . Furthermore, this indicated that there is a correlation between the involvement and the QWL of the workers in the packer and loader department Tuban IVth plant.

\section{The Correlation between Balanced Compensations and Quality of Work Life}

The results of the Spearman's correlation test on the balanced compensation and QWL are presented in Table 5. As noticed, there was only one respondent whose scores of balanced compensations and QWL are low, while the respondents whose score of balanced compensation was high attained a moderate-score of QWL (50\%).

By referring to Table 5, it is known that there was only one respondent with low scores of balanced compensations and QWL. On the other hand, the respondents whose score of balanced compensations was high $(50 \%)$ were noticed to have a moderatescore of QWL. In addition, from the Spearman's rho statistical test, it was disclosed that the significance value of the two variables was 0.017 , which implied that there is a significant correlation with the correlation coefficient value of 0.354 . Thus, it can be disclosed that in this research, there is a positive correlation between balanced compensations and QWL.

Table 3. The Frequency Distribution of the Packer and Loader Workers based on the Level of Quality of Work Life in 2018

\begin{tabular}{ccc}
\hline Level of QWL & Frequency (n) & Percentage (\%) \\
\hline Low & 8 & 17.8 \\
Moderate & 30 & 66.7 \\
High & 7 & 15.6 \\
\hline Total & 45 & 100 \\
\hline
\end{tabular}

\section{The Correlation between A Sense of Security towards the Work and Quality of Work Life}

Spearman's correlation test was applied to identify the correlation between a sense of security towards the work and QWL in this research. Based on the results showed in Table 6, it can be concluded that more than half of the respondents $(55.6 \%)$ who had a low-score of a sense of security towards the work also had a low-score of QWL. Furthermore, the results of the test showed a significant value of 0.000 , which suggested that there is a significant and positive correlation between the two variables with the correlation coefficient value of 0.610 . Thus, it can be affirmed that if the company increases the sense of security towards the work, the QWL of the workers will also improve.

\section{The Correlation between Occupational Safety and Health and Quality of Work Life}

The correlation between occupational safety and health and QWL of the workers was measured by implementing the Spearman's correlation test. The results presented in Table 7 denoted that the greater part of the respondents $(71.4 \%)$ whose score of occupational safety and health was low, also had a low-score of QWL. Moreover, the test showed a significant value of 0.000 , indicating that there is a positive significant correlation between the two variables with the correlation coefficient value as much as 0.681 . Hence, it is affirmed that if the company pays more attention to occupational safety and health, the higher score of QWL can be obtained.

\section{The Correlation between Career Development and Quality of Work Life}

The correlation between career development and QWL was measured by using Spearman's correlation test which results are displayed in Table 8. Based on the results, it is noticed that $53.3 \%$ of the

Table 4. The Correlation between the Packer and Loader Workers' Involvement and Quality of Work Life in 2018

\begin{tabular}{|c|c|c|c|c|c|c|c|c|}
\hline \multirow{3}{*}{$\begin{array}{c}\text { Workers' } \\
\text { Involvement }\end{array}$} & \multicolumn{6}{|c|}{ Level of QWL } & \multirow{2}{*}{\multicolumn{2}{|c|}{ Total }} \\
\hline & \multicolumn{2}{|c|}{ Low } & \multicolumn{2}{|c|}{ Moderate } & \multicolumn{2}{|c|}{ High } & & \\
\hline & $\mathbf{n}$ & $\%$ & $\mathbf{n}$ & $\%$ & $\mathbf{n}$ & $\%$ & $\mathbf{N}$ & $\%$ \\
\hline Low & 2 & 40 & 3 & 60 & 0 & 0 & 5 & 100 \\
\hline Moderate & 6 & 28.6 & 12 & 57.1 & 3 & 14.3 & 21 & 100 \\
\hline High & 0 & 0 & 15 & 78.9 & 4 & 21.1 & 19 & 100 \\
\hline
\end{tabular}


Table 5. The Correlation between Balanced Compensations and Quality of Work Life of the Packer and Loader Workers in 2018

\begin{tabular}{|c|c|c|c|c|c|c|c|c|}
\hline \multirow{3}{*}{$\begin{array}{c}\text { Balanced } \\
\text { Compensation }\end{array}$} & \multicolumn{6}{|c|}{ Level of QWL } & \multirow{2}{*}{\multicolumn{2}{|c|}{ Total }} \\
\hline & \multicolumn{2}{|c|}{ Low } & \multicolumn{2}{|c|}{ Moderate } & \multicolumn{2}{|c|}{ High } & & \\
\hline & $\mathbf{n}$ & $\%$ & $\mathbf{n}$ & $\%$ & $\mathbf{n}$ & $\%$ & $\mathbf{N}$ & $\%$ \\
\hline Low & 1 & 33.3 & 2 & 66.7 & 0 & 0 & 3 & 100 \\
\hline Moderate & 5 & 19.2 & 20 & 76.9 & 1 & 3.8 & 26 & 100 \\
\hline High & 2 & 12.5 & 8 & 50 & 6 & 37.5 & 16 & 100 \\
\hline
\end{tabular}

Table 6. The Correlation between A Sense of Security towards the Work and Quality of Work Life of the Packer and Loader Workers in 2018

\begin{tabular}{|c|c|c|c|c|c|c|c|c|}
\hline \multirow{3}{*}{$\begin{array}{l}\text { A Sense of } \\
\text { Security } \\
\text { towards the } \\
\text { Work }\end{array}$} & \multicolumn{6}{|c|}{ Level of QWL } & \multirow{2}{*}{\multicolumn{2}{|c|}{ Total }} \\
\hline & \multicolumn{2}{|c|}{ Low } & \multicolumn{2}{|c|}{ Moderate } & \multicolumn{2}{|c|}{ High } & & \\
\hline & $\mathbf{n}$ & $\%$ & $\mathbf{n}$ & $\%$ & $\mathbf{n}$ & $\%$ & $\mathbf{N}$ & $\%$ \\
\hline Low & 5 & 55.6 & 4 & 44.4 & 0 & 0 & 9 & 100 \\
\hline Moderate & 3 & 25.0 & 9 & 75.0 & 0 & 0 & 12 & 100 \\
\hline High & 0 & 0 & 17 & 70.8 & 7 & 29.2 & 24 & 100 \\
\hline
\end{tabular}

Table 7. The Correlation between Occupational Safety and Health and Quality of Work Life of the Packer and Loader Workers in 2018

\begin{tabular}{|c|c|c|c|c|c|c|c|c|}
\hline \multirow{3}{*}{$\begin{array}{c}\text { Occupational } \\
\text { Safety and } \\
\text { Health }\end{array}$} & \multicolumn{6}{|c|}{ Level of QWL } & \multirow{2}{*}{\multicolumn{2}{|c|}{ Total }} \\
\hline & \multicolumn{2}{|c|}{ Low } & \multicolumn{2}{|c|}{ Moderate } & \multicolumn{2}{|c|}{ High } & & \\
\hline & $\mathbf{n}$ & $\%$ & $\mathbf{n}$ & $\%$ & $\mathbf{n}$ & $\%$ & $\mathbf{N}$ & $\%$ \\
\hline Low & 5 & 71.4 & 2 & 28.6 & 0 & 0 & 7 & 100 \\
\hline Moderate & 3 & 11.1 & 23 & 85.2 & 1 & 3.7 & 12 & 100 \\
\hline High & 0 & 0 & 5 & 45.5 & 6 & 54.5 & 11 & 100 \\
\hline
\end{tabular}

respondents with a high-score of career development also had a high-score of QWL. In addition, the test obtained a significance value of 0.001 . In other words, this entailed that there is a positive significant correlation between the career development and QWL of the workers. Moreover, the correlation coefficient value of as much as 0.465 indicated that a good career development provided by the company will result in a good QWL of the workers.

\section{The Correlation between Working Relationship and Quality of Work Life}

According to Table 9 that presents the results of Spearman's correlation test on the working relationship and QWL of the packer and loader workers, it is perceived that $60 \%$ of the respondents with a low-score of working relationship also had a low-score of QWL. Moreover, Spearman's correlation test attained a significance value of 0.008 , which meant that there is a positive significant correlation between the two variables with the correlation coefficient value of 0.392 . Or else, it can be stated that the better the working relationship between workers and the company, the better the QWL experienced by the workers.

\section{The Correlation between Pride in the Company and Quality of Work Life}

Table 10 shows the results of the Spearman's correlation test carried out regarding the sense of pride and the QWL of the workers. The test indicated that more than half of the respondents $(55.6 \%)$ whose score of sense of pride in the company was high also had a high-score of QWL. Additionally, the significance value of the test, which was as much as 0.000 , implied that there is a positive 
Table 8. The Correlation between Career Development and Quality of Work Life of the Packer and Loader Workers in 2018

\begin{tabular}{|c|c|c|c|c|c|c|c|c|}
\hline \multirow{3}{*}{$\begin{array}{c}\text { Career } \\
\text { Development }\end{array}$} & \multicolumn{6}{|c|}{ Level of QWL } & \multirow{2}{*}{\multicolumn{2}{|c|}{ Total }} \\
\hline & \multicolumn{2}{|c|}{ Low } & \multicolumn{2}{|c|}{ Moderate } & \multicolumn{2}{|c|}{ High } & & \\
\hline & $\mathbf{n}$ & $\%$ & $\mathbf{n}$ & $\%$ & $\mathbf{n}$ & $\%$ & $\mathbf{N}$ & $\%$ \\
\hline Low & 2 & 50 & 2 & 50 & 0 & 0 & 4 & 100 \\
\hline Moderate & 5 & 19.2 & 20 & 76.9 & 1 & 3.8 & 26 & 100 \\
\hline High & 1 & 6.7 & 8 & 53.3 & 6 & 40.0 & 15 & 100 \\
\hline
\end{tabular}

Table 9. The Correlation between Working Relationship and Quality of Work Life of Packer and Loader Workers in 2018

\begin{tabular}{|c|c|c|c|c|c|c|c|c|}
\hline \multirow{3}{*}{$\begin{array}{c}\text { Work } \\
\text { Relationship }\end{array}$} & \multicolumn{6}{|c|}{ Level of QWL } & \multirow{2}{*}{\multicolumn{2}{|c|}{ Total }} \\
\hline & \multicolumn{2}{|c|}{ Low } & \multicolumn{2}{|c|}{ Moderate } & \multicolumn{2}{|c|}{ High } & & \\
\hline & $\mathbf{n}$ & $\%$ & n & $\%$ & $\mathbf{n}$ & $\%$ & $\mathbf{N}$ & $\%$ \\
\hline Low & 3 & 60 & 2 & 40 & 0 & 0 & 5 & 100 \\
\hline Moderate & 5 & 17.9 & 19 & 67.9 & 4 & 14.3 & 28 & 100 \\
\hline High & 0 & 0 & 9 & 75 & 3 & 25 & 12 & 100 \\
\hline
\end{tabular}

Table 10. The Correlation between Pride in the Company and Quality of Work Life of Packer and Loader Workers in 2018

\begin{tabular}{|c|c|c|c|c|c|c|c|c|}
\hline \multirow{3}{*}{$\begin{array}{l}\text { A Sense of } \\
\text { Pride to the } \\
\text { Company }\end{array}$} & \multicolumn{6}{|c|}{ Level of QWL } & \multirow{2}{*}{\multicolumn{2}{|c|}{ Total }} \\
\hline & \multicolumn{2}{|c|}{ Low } & \multicolumn{2}{|c|}{ Moderate } & \multicolumn{2}{|c|}{ High } & & \\
\hline & n & $\%$ & $\mathrm{n}$ & $\%$ & $\mathbf{n}$ & $\%$ & $\mathbf{N}$ & $\%$ \\
\hline Low & 2 & 50 & 2 & 50 & 0 & 0 & 4 & 100 \\
\hline Moderate & 6 & 18.8 & 24 & 75 & 2 & 6.3 & 32 & 100 \\
\hline High & 0 & 0 & 4 & 44.4 & 5 & 55.6 & 9 & 100 \\
\hline
\end{tabular}

significant correlation between two variables with the correlation coefficient value of 0.524 .

\section{DISCUSSION}

\section{The Correlation between Individual Characteristics and Quality of Work Life}

By referring to the research that has been carried out, it is observed that the workers at PT Semen Indonesia (Persero) Tbk whose 31-40 years old are satisfied with their current job. This happens because the workers with an older age feel more Besides, according to Wijono (2010), the age of an individual is one of the most important factors that influence the perception of job satisfaction.

The high school graduates' workers are noticed as having high and moderate levels of job satisfaction. However, the education background and the level of intelligence of a person are yet to be precisely related to the job satisfaction that $\mathrm{s} / \mathrm{he}$ has (Wijono, 2010).

As for another factor, namely marital status, it is noticed from the data obtained that the majority of the workers are married. Maulidhina (2018) affirmed that a married person will get career support from the family, such as from the wife or the husband. Consequently, a married person will be easier to attain job satisfaction.

Next, workers with long years of service are believed to be more experienced. In addition, experienced workers are able to cope with various work situations and adjust to changes in their surroundings (Irkhami, 2015). Furthermore, Irkhami (2015) added that experienced workers may get more opportunities to develop their work-ability and skills. Thus, they will acquire job satisfaction more easily. 
Therefore, based on the research, it can be disclosed that job satisfaction has a close relationship with QWL. This is proven by the fact that all workers with low QWL tend to have a low level of job satisfaction. On the contrary, workers with high QWL are noticed to have high and moderate levels of job satisfaction.

\section{The Correlation between the Workers' Involvement and Quality of Work Life}

The workers' involvement is indicated by both the mental and emotional involvement of the people in a particular group that encourages them to together form the goals and share the responsibility to achieve those goals (Cascio and Aguinis, 2005). The workers' involvement provides freedom to the workers to actively make decisions regarding their job. Thus, the more the workers involve in the working activity, the more responsible they will be in performing their work (Siagian, 2012). The questionnaire distributed to the respondents obtained a result that the workers are given an authority to perform the work and that every decision in the workplace must be approved by all workers. The workers must be involved in every decision-making activity. However, every now and then, according to the respondents, not all workers are being involved in decision-making activities; only the experienced workers are allowed to be involved. Whereas, the workers' involvement is one of the indicators of good QWL, especially to realize job satisfaction, motivation, and productivity. Furthermore, it is affirmed that a good involvement of the workers will make the workers feel appreciated which can result in an increase in job satisfaction (Cascio, 1998).

Overall, the results of this research are in accordance with the theory proposed by Cascio (1998), which claimed that a good involvement of the workers will result in a good QWL. However, the programs to increase the workers' involvement in a workplace need to be carried out through a participatory leadership type, in which the workers have the right to give suggestions and considerations in a decision-making process.

\section{The Correlation between Balanced Compensations and Quality of Work Life}

Compensation is an essential component in the relationship between workers and the company, which comprises non-financial and financial compensations (Mangkunegara, 2006). Cascio (1998) added that good QWL needs to be complemented by balanced compensations. Compensations provided to workers can realize the QWL has the company had a fair wage system, undoubtedly, and in line with the workers' expectations and the work is done. Furthermore, wages must also be given based on work demands, individual skills, and the community wage standard (Robbins, 2001).

The respondents at PT Semen Indonesia affirmed that the compensation given by the company is fair and in accordance with the work they perform. Other than that, the company itself has the policy to determine the incentive according to the type of work, the financial status of the company, and the government policy. Additionally, compensations are given based on the work assessment as a basis for the reward and punishment system. However, some of the workers, especially those who are married, feel that their income is not enough to support their family. Furthermore, the workers also stated that non-financial awards in the form of compliment, letters of appreciation, medals, or prizes for the workers with a good work performance have not yet been given by the company. Whereas, non-financial awards are also things that the company needs to pay attention to since it will meet the workers' needs of awards to achieve job satisfaction. Among others, internal respect is also considered as a non-financial award.

\section{The Correlation between A Sense of Security towards the Work and Quality of Work Life}

The realization of a sense of security towards the work can be carried out in the form of pension and the certainty of the status of the workers so that they can focus on doing their work (Cascio, 1998). The certainty of the status of the workers has been regulated in the President of Republic of Indonesia (2013) so that every company is obligated to provide a clear working contract as well as to provide a pension for the workers who stop working due to the dismissal.

The results of the research disclosed that the majority of the workers obtained a high-score on the perception of the sense of security towards the work. In broad, the workers agreed that the work they do has been in accordance with their wishes regarding the freedom to complete the work.

The questionnaire distributed to the respondents indicated that the lowest scores were obtained at two aspects: the possibility of the dismissal and the feeling of insufficient pension guarantee. This fact 
alone showed that there is a discrepancy between the written company programs, in which all workers must join the employment insurance consisting of pension and occupational accident insurance, and the given working contract.

For that reason, communication between the company and the workers needs to be carried out to avoid the concern of the workers regarding this matter. A sense of security towards the work according to the prior research and this research is considered as one of the factors that can realize a good QWL. Hence, it is critical for the company to pay attention to this factor.

\section{The Correlation between Occupational Safety and Health and Quality of Work-Life}

President of Republic of Indonesia (2013) article 86 paragraph (1) letter (a) mentioned that employers must carry out occupational health integrated with the company management system, providing occupational health is one of the rights of a worker. This endeavor can be realized by preventing the occurrence of occupational accidents and occupational diseases, hazard control in a workplace, health promotion, medication, and rehabilitation. The endeavor of occupational safety and health aims to protect the workers, as well as to achieve optimum work productivity.

Referring to the workers themselves, the packer and loader department is the department in which physical effort is fundamental. Nonetheless, most of the workers feel helped by safe working facilities, namely the maintenance crew of the packer and loader machines, so the machine damage that endangers the workers is very rare. Other than that, the working environment in the packer and loader area tends to be dusty from the cement produced by the packer and loader machines. In this case, the company provides control by providing personal protective equipment, such as masks, safety shoes, safety helmets, and work uniforms.

The results of the questionnaire denoted that according to the workers, the monitoring of the work condition is not directly performed by the supervisor, yet it is performed by the occupational safety officer. However, the company shows the commitment to occupational safety and health through the policy regulating occupational and environmental safety and health, which is written in the Guidelines for implementing Good Corporate Governance by meeting the requirements for occupational safety and health in accordance with the applicable laws and regulations. The other criterion with a lowscore is the work stress. The workers in the packer and loader department Tuban IVth plant affirmed that they suffer from stress caused by boredom and monotonous works.

The statistic test result indicated that there is a positive significant correlation between occupational safety and health and the QWL. Thus, if the occupational safety and health of the workers are fulfilled by the company, the QWL of the workers may improve. The fulfillment of this factor indeed is one of the fulfillment of the rights of the workers; to provide a safe working environment, so the workers do not have to worry about their safety in the workplace.

\section{The Correlation between Career Development and Quality of Work-Life}

Career development is a notable aspect of being the company's concerns, providing that it is one-factor influences the workers' perception of job satisfaction (Mangkunegara, 2006). The workers must obtain guarantees of their career, in the hope that they will continue to develop. Several programs can be carried out with the intention to develop the career of the workers, such as providing education, workshop, performance evaluation, and promotion. A good career development provided by the company is believed as a motivation for the workers to perform their works better as well as to avoid work frustration that can result in the decline in the company's performance (Cascio and Aguinis, 2005).

Career development referred to in this research is the workers' perception of the opportunity to get more knowledge, to improve their skills, and to achieve work promotion. The results of the questionnaire distributed to the respondents denoted that most of the workers affirmed if they are given opportunities by the company to initiative solve problems and carry out their works based on the applicable standard. It was also noticed that the company has provided various facilities for the workers to get more knowledge and to improve their skills, such as workshop programs related to their field of work.

However, the development outside of work has not yet been given enough attention by the company. It was stated that the company held a workshop regarding occupational safety and health in the form of Off The Job Training. Nonetheless, that workshop was only provided for the workers in the machine 
maintenance and central control room departments, and the packer and loader workers could not attend the workshop. Even so, it is to be noted that the company has its own guidelines for promotion in the career development policy, as long as the workers meet the specific requirements.

The bivariate analysis by implementing Spearman's correlation test indicated that there is a significant moderate correlation between career development and the QWL of the workers. If the career development provided by the company is well-carried out, the QWL of the workers can be easily achieved.

The fulfillment of career development is one form of the fulfillment of the workers' needs to develop and to gain more knowledge aside from the fact that it can help the workers to complete their daily works. Therefore, it is crucial for the company to provide career development programs for the workers based on the characteristics and the type of work.

\section{The Correlation between Working Relationship and Quality of Work-Life}

The working relationship discussed in this research is the workers' perception of the relationship between themselves and their coworkers as well as their leaders, open communication, and the company's effort in solving problems. Communication holds a crucial role in the relationship within an organization, whether it is among the coworkers or between workers and the leaders. Good communication involves communicators; in this case, the leader and the workers. Moreover, good communication in an organization can increase the work motivation, which leads to an increase in job satisfaction and work performance of the workers. Furthermore, conflict resolution can be done by company members openly; a formal process of problem-solving and exchange of opinions (Cascio and Aguinis, 2005).

The results of the questionnaire implied that the exchange of information among coworkers can be easily done due to the development of information technology. Conversely, the workers still feel that sometimes, the information from the leader has not been conveyed properly and thoroughly with the media that can be accessed by the workers.

Periodic meetings have been carried out by the company, whether it is a daily meeting before work or a weekly meeting to report the evaluations and handling negative discoveries, yet the workers still feel that the presence of the leader does not help much in delivering information. In addition, the packer and loader workers stated that conflict among coworkers is very rare due to the fact that all workers feel they have a bond for having been working in a long time and have a fair job division.

The bivariate analysis denoted that there is a positive significant correlation between the working relationship and the QWL of the workers. A good working relationship in an organization will provide convenience for the workers to complete their work. Additionally, the respondents affirmed that the working relationship does influence the working process providing they have to form a group and interact with one another while working.

\section{The Correlation between Pride in the Company and Quality of Work-Life}

A sense of belonging to a company may arise if the workers are proud of their workplace and their job. The pride of the workers can be realized by strengthening the identity and image of the company, increasing public participation, and caring more of the environment(Cascio and Aguinis, 2005).

Based on the questionnaire that has been distributed to the respondents, it can be distinguished that the workers believed they are obliged in maintaining the good image of the company by complying with all applicable rules and complete the work according to the instructions and responsibilities. The workers also find it hard to leave the company since they feel that they have obligations to the people within the company and hard to quit their job with the consideration that finding work elsewhere is quite difficult. However, some of the workers have not felt proud of their current job even though they work in a big prestigious company because they still have the expectation to have a better job.

The correlation test of these two variables showed a significant correlation. Furthermore, increasing pride in the company can also be done by increasing pride externally and internally. Externally, it can be done by improving the image of the company through social services that can be directly received by the public. On the other hand, internally, pride in the company can be increased by creating a comfortable work atmosphere, increasing a sense of responsibility of the workers, and maintaining a sense of belonging to the company. PT Semen Indonesia is a State-owned Enterprise that is obligated to give more attention to the public 
whose resident is around the factory by carrying out Corporate Social Responsibility as an effort to maintain a harmonious relationship between the company and the public.

\section{CONCLUSION}

According to the analysis, it was discovered that the assessment regarding the factors of QWL, namely the workers' involvement, balanced compensations, occupational safety and health, career development, working relationship, and pride in the company attained a moderate score. In addition, the factor of a sense of security towards the work attained a high score. To complement, the QWL of the workers was also noticed attaining a moderate score.

The results of the analytical test denoted that there is a significant correlation between a sense of security towards the work, workers' involvement, balanced compensations, occupational safety and health, career development, working relationship, and pride in the company and the QWL of the workers. Furthermore, it was disclosed that those factors need to be fulfilled by the company to realize a good QWL of the workers.

\section{ACKNOWLEDGMENTS}

The authors would like to acknowledge Indriati Paskarini, S.H., M.Kes as the supervisor of this research.

\section{REFERENCES}

Cascio, W. F. (1998) Managing Human Resources: Productivity, Quality of Work Life, Profits. 5th edn. Boston: Irwin McGraw-Hill.

Cascio, W. F. and Aguinis, H. (2005) Applied Psychology in Human Resource Management. 6th edn. New Jersey: Prentice Hall.

Dhamayanti, A. (2017) Analisis Kepuasan Karyawan Melalui Faktor-Faktor "Quality of Work Life (QWL)" di PT Inti Abadi Kemasindo. Undergraduate Thesis. Bogor: Faculty of Economics and Management, Bogor Agricultural University.
Hasibuan, M. S. . (2005) Manajemen Sumber Daya Manusia. Revision,. Jakarta: Bumi Aksara.

Irkhami, F. L. (2015) 'Faktor yang Berhubungan dengan Stres Kerja pada Penyelam Di PT. X', The Indonesian Journal of Occupational Safety and Health, 4(1), p. 54.

Jati, A. N. (2013) 'Kualitas Kehidupan Kerja dan Komitmen Organisasional: Hubungannya dengan Organization Citizenship Behavior', Kiat BISNIS, 5(2), pp. 86-91.

Lian, W., Lin, M. and Wu, K. (2007) 'Job Stress, Job Satisfaction and Life Satisfaction between Managerial and Technical is Personnel', in Proceedings of Business and Information, pp. $1-17$.

Mangkunegara, A. P. (2006) Manajemen Sumber Daya Manusia Perusahaan. Bandung: PT. Remaja Rosdakarya.

Maulidhina, R. (2018) Hubungan Kualitas Kehidupan Kerja dengan Kepuasan Kerja pada Tenaga kerja Bagian Produksi di PT. Semen Indonesia (Tbk) Pabrik Tuban. Undergraduate Thesis. Surabaya: Faculty of Public Health, Universitas Airlangga.

National Institute of Occupational Safety and Health (2013) Quality of Work Life Questionnaire, Center for Disease Control and Prevention.

President of Republic of Indonesia (2013) UndangUndang Republik Indonesia No. 13 Tahun 2003 tentang Ketenagakerjaan. Jakarta: President of Republic of Indonesia.

Robbins, S. P. (2001) Perilaku Organisasi: Konsep, kontroversi, Aplikasi. Jakarta: Pranha Ilindo.

Sekaran, U. (2006) Metodologi Penelitian untuk Bisnis. 4th edn. Jakarta: Salemba Empat.

Siagian, S. P. (2012) Manajemen Sumber Daya Manusia. Jakarta: Bumi Aksara.

Suci, S. I. M. (2017) Hubungan Beban Kerja Mental dan Tingkat Monotonitas dengan Stres Kerja pada Pekerja Packer dan Loader PT. Semen Indonesia (Persero) Tbk. Tuban. Undergraduate Thesis. Surabaya : Faculty of Public Health, Universitas Airlangga.

Wijono, S. (2010) Psikologi industri dan organisasi. Jakarta: Kencana. 